\title{
Am I Allowed to Laugh? Students' Perception Towards the Use of Humor in English Class
}

\author{
$1^{\text {st }}$ Desy Eva Laila Rokhmah* \\ Department of English Education \\ Universitas Musamus \\ Merauke, Indonesia \\ desyeva_pbi@unmus.ac.id
}

\author{
$2^{\text {nd }}$ Martha Betaubun \\ Department of English Education \\ Universitas Musamus \\ Merauke, Indonesia \\ marthabetaubun@unmus.ac.id
}

\author{
$3^{\text {rd }}$ Casimirus Andy Fenanlampir \\ Department of English Education \\ Universitas Musamus \\ Merauke, Indonesia \\ fenanlampir@unmus.ac.id
}

\begin{abstract}
Humor is a form of communication that tend to create amusement and trigger laughter. Research has proven that humor is beneficial for physical health, psychological wellbeing and social interaction. As a communication tool, humor benefits both the sender and receiver. It reduces anxiety, creates positive atmospheres, and breaks down barriers. In the classroom teaching context, humor can be used as one of the instructional tools which help students to engage in the teaching and learning process, especially in teaching English. There is no doubt that learning a foreign language can be very toilsome as it involves many processes. Students have to struggle with language anxiety such as apprehension, self doubt, and frustration which eventually leads to stress and boredom. Therefore, teachers should consider the students' mental state when delivering the material by choosing the appropriate form of classroom instruction. This study aims to investigate students' perception of using humor as one of classroom instructional models in teaching English as a Foreign Language. It was conducted to 60 students of English Education Department, at Musamus University of Merauke. The result indicates that the use of humor in teaching English may have positive impacts as it creates a more relaxing environment for the students; and in addition, it also helps the students to have better retention of the material being taught.
\end{abstract}

Keywords: humor, classroom instruction, teaching English as a foreign language

\section{INTRODUCTION}

Recently, there are various forms of comedy programs such as standup comedy, sitcom, game show, animated cartoon and many more are aired on broadcasting media. The ratings of these shows also continue to increase over the years. It is shown that the humor elements in comedy have captivated people's attention. It is not surprising because people believe that humor can bring pleasure and creates the sensation of happiness when they laugh upon hearing or watching humorous things. This credence is reflected in the famous slogan "laughter is the best medicine".

Number of researches have revealed that humor is beneficial to human in many aspects such as physical, psychological, and social interaction. Humor is also believed to have significant contributions in educational domain [1-3] Especially in foreign language teaching [4], humor may serve as a powerful tool to attract the learners. Therefore, this study is designed to explore the perceptions of English as a
Foreign language learners regarding the use of humor in classroom interaction.

The term humor came from the Latin word means "moisture". In the old use, humor refers to the body fluids such as blood, phlegm, yellow bile, and black bile. It was believed that the balance of these four fluids indicates one's health condition and disposition [5]. In the Renaissance era, "humor" was used to describe an unstable mental state or sanity. The meaning of the word began to shift in the 18th century which was used to describe one's normal behavior [6].

There are numbers of definitions of humor. It depends on the elements which being observed. In the Oxford Advance Learner's dictionary, humor is defined as the quality in something that makes it funny or the ability to laugh at things that are amusing [7]. Accordingly, the Merriam-Webster dictionary defines humor as the mental faculty of discovering, expressing or appreciating something that is comical, amusing, or absurdly incongruous [5].

Based on the communicative perspective, Robinson provided a brief definition. He stated that humor is "any communication perceived by any of the interacting parties as humorous and leads to laughing, smiling, or a feeling of amusement" [6]. From linguistics point of view, humor can be defined as an act performed through linguistic or nonlinguistic means by any of the participants. Raskin stated that the act is the result of two incongruous scripts; a cognitive structure internalized by the native speaker and represents the native speaker's knowledge of a small part of the world [8].

In modern usage, generally "humor" is used to describe the quality of being amusing or something that triggers laughter. However, research has proven that humor is not just a laughing matter. Humor benefits human's physical health because it strengthens the immune system. A research conducted by Bennet revealed that laughter may improve immune function by blocking production of stress hormones, such as cortisol, and by increasing the release of immunoenhancers, such as beta-endorphin [9]. Humor also promote productivity as it stimulates overall brainpower. A dose of humor releases the chemical serotonin in human brain, which improves focus, increases objectivity and improves overall brainpower [10]. Surprisingly, laughter also 
burns calories; laughing 100 times equals to 10 (ten) minutes on a stationary bicycle [11].

Humor is beneficial for psychological well - being because it helps people to cope with negative or threatening circumstances [12], dealing with stress, and enhance the ability to solve problem as well. Facing with the same number of problems at work, people with a sense of humor are reported to have less stress and anxiety than those with a low sense of humor [13]. Studies also have shown that watching comedy films can improve creative problem solving [14].

As a form of communication, humor helps people to build social interactions as it diffuses conflict and gets people to listen. Humor is considered as a means to facilitate conversation and bridge differences. In fact, humor has been identified as a key factor in peace - building and international mediation [15]. Humor can be remarkably persuasive. When presenting a message that people might disagree with, humor distracts them from creating counter arguments immediately [16].

Considering many benefits mentioned above, in the educational context, humor may assist learning, especially in teaching English as a Foreign Language. Presumably, learning foreign language is not an easy job. It requires learners' continuous efforts and persistence. Along the process, students might face many obstacles and unpleasant circumstances. Students have to struggle with language anxiety such as apprehension, self - doubt, and frustration which eventually leads to stress and boredom. Krashen [1] noted that anxiety brings negative effects on the student's ability to learn a second language (L2). Therefore, teachers are expected to observe and aware of learners' mental state, and find the appropriate way to deliver the material which make the students feel comfortable during the teaching and learning process so that they can engage in learning as well. By utilizing humor in a classroom communication, students will develop the sense that the teacher is more approachable, and at the same time improve student-teacher relationships and develop student involvement in the lesson. Berk [2] argued that humor can help the teachers to pave the way for students' learning enhancement.

As it helps to boost brainpower, humor may help students to have better retention of the material being taught. Study has been shown that the use of humor as a pedagogical tool can reduce classroom anxiety, create a more positive atmosphere, and facilitate the learning process as well [3]. However, Kaplan and Pascoe reminded that humor needed to be relevant to the instructional material to increase learning [17]. Morrison pointed out that humor benefits the classroom teaching by creating an optimal learning environment, facilitates communication, enhances creativity, maximizes brain power, contributes to a healthy mind and body balance, and supports the change process [18].

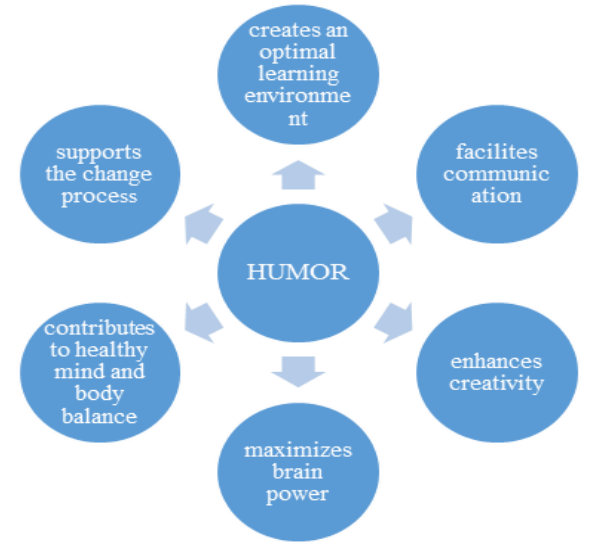

Fig. 1. Benefits of Humor [18]

\section{RESEARCH METHODS}

This study aimed to survey the students' perception toward the use of humor as a form of classroom instruction in teaching English. It was a pilot study; therefore, the quantitative approach was chosen for the research design. Purposive sampling was used in selecting 60 respondents from English Education Department, Faculty of Teacher Training and Education of Musamus University of Merauke, Papua, Indonesia. The sample were chosen because most of their subjects are related to English language course and mostly delivered in English.

The data presented in this research were collected using a questionnaire adapted from Morrison [18], and modified based on the requirement of the research. It consisted of several items related to the purpose of the research. There were several close-ended questions regarding students' opinion toward the use of humor as a classroom instructional tool in teaching English. The questionnaires were administered to the students at the end of the courses. This study was conducted on 2019/2020 academic year. In order to simplify the process and maintain the sufficient time, the questionnaires were distributed online via google form.

\section{RESUlt AND Discussion}

The following data are taken from the questionnaires which have been administered to sixty (60) students of English Education Department of Musamus University of Merauke. The overall result of students' responses as the basis of descriptive statistical analysis are presented in table and chart. The explanation of each item being inquired is as follows:

\section{A. The Use of Humor Makes Me Relax and Helps Me Reduce Stress in Learning English}

It was found that the majority of the students responded positively on the statement related to the relaxing effect on the use of humor. The data is presented in table 1 below. The (n) represents the number of the respondent. 
TABLE I. STUDENTS’ RESPONSES ON QUESTION (1)

\begin{tabular}{|c|c|c|}
\hline Response & N & $\%$ \\
\hline Agree & 60 & 100 \\
\hline Disagree & 0 & 0 \\
\hline No idea & 0 & 0 \\
\hline
\end{tabular}

As the data shown in table 1 , all of the respondents or $100 \%(n=60)$ agreed to the statement that "the use of humor makes me relax and helps me to reduce the stress in learning English". This finding suggests that psychologically, humor has a significant impact on students' mental state. Stress can hinder students' cognitive function and negatively affect students' academic performance. The teaching learning process in the classroom also cannot run smoothly if the students are tense or felt like they are under pressure. By employing humor in the classroom interaction, especially on a difficult course like English Language, teacher can provide a more relaxing learning environment and reduce stress.

\section{B. Humor Bridges the Gap Between Lecturers and The Students}

The data in table 2 shows the students' responses related to the statement about whether the humor usage in English teaching can be utilized as a tool for the teacher to get closer the students.

TABLE II. STUDENTS' RESPONSES ON QUESTION (2)

\begin{tabular}{|c|c|c|}
\hline Response & N & \% \\
\hline Agree & 49 & 82 \\
\hline Disagree & 8 & 13 \\
\hline No idea & 3 & 5 \\
\hline
\end{tabular}

From the data in table 2 above, it can be seen that forty-nine (49) of the students ( $82 \%)$ agreed that humor helps them to bridge the gap with the lecturers; 8 (Eight) students (13\%) were against it, and 3 (three) students had no idea. This finding is in line with Morrison [18] who argued that humor facilitates communication. When the students laugh to humor inserted during the learning process, it develops the sense of equality. Thus, the students will feel that the lecturer is approachable and closer to them.

\section{Humor Makes the English Class More Interesting}

Positive responses were also shown on the statement "the use of humor makes the English class more interesting". The data can be seen in the following table.

TABLE III. STUDENTS' RESPONSES ON QUESTION (3)

\begin{tabular}{|c|c|c|}
\hline Response & $\mathbf{n}$ & \% \\
\hline Agree & 57 & 95 \\
\hline Disagree & 2 & 3 \\
\hline No idea & 1 & 2 \\
\hline
\end{tabular}

The data in table 3 shows that 57 students or $95 \%$ of the respondents agreed to the statement. However, two (2) students or $3 \%$ of the respondents stand against it, and only one (1) students $(2 \%)$ responded with "no idea". This finding supports the idea that humor fosters positive learning environment which eventually enhanced students' engagement to the lesson. No matter how difficult the subject is; if the learners felt that the subject is interesting, they will put effort to learn.

\section{The Use of Humor Encourages the Students to Attend the Class}

The percentage of students' responses on question number 4 is almost identical to question number 2 . The data can be seen clearly in table 4 below. Seventy - five percent $(75 \%)$ of the population or 45 students agreed that "humor encourages the students to attend the class".

TABLE IV. STUDENTS' RESPONSES ON QUESTION (4)

\begin{tabular}{|c|c|c|}
\hline Response & n & \% \\
\hline Agree & 45 & 75 \\
\hline Disagree & 15 & 25 \\
\hline No idea & 0 & 0 \\
\hline
\end{tabular}

However, the data finding indicates that although most of the students agree that the use of humor in classroom instruction makes the learning environment become more enyoyable, but it does not necessarily promote class attendance. It was proven by a significant number of the students selected "disagree" option with the total of fifteen (15) students or $25 \%$ of the population., and none of them selected "No idea".

\section{E. The Use of Humor Helps Me to Understand and Remember the Material Being Taught Easily}

Lastly, fifty - eight (58) students (97\%) agreed to the statement that "the use of humor helps me to understand and remember the material being taught easily", and two (2) students $(3 \%)$ disagreed. The data can be seen clearly in the table 5 below.

TABLE V. STUDENTS' RESPONSES ON QUESTION (5)

\begin{tabular}{|c|c|c|}
\hline Response & $\mathbf{n}$ & \% \\
\hline Agree & 58 & 97 \\
\hline Disagree & 2 & 3 \\
\hline No idea & 0 & 0 \\
\hline
\end{tabular}

The result as explained in table 5 above is coherent with the previous study [1-3], [18] which stated that humor can be utilized as a pedagogical tool because it boosts brainpower and foster better memory retention of the subject being learned. From this preliminary finding, it can be implied that there are other factors which affect classroom attendance. Thus, to see the bigger picture, further investigation is needed to be carried out.

The comparison of students' responses on all questions related to the use of Humor in teaching English as a Foreign Language can be seen in table 6 below. The distribution of students' agreement to all statement is extremely high as illustrated in figure 2. Meanwhile, the distribution of students' disagreement can be seen in figure 3. As can been in the chart, the highest negative response was on the statement (4) that humor encourage the students to attend the class. 
TABLE VI. RECAPITULATION OF STUDENTS' RESPONSES

\begin{tabular}{|c|c|c|c|c|c|c|c|}
\hline \multirow[t]{2}{*}{ NO } & \multirow[t]{2}{*}{ Questions } & \multicolumn{2}{|c|}{ Agree } & \multicolumn{2}{|c|}{$\begin{array}{c}\text { Disagr } \\
\text { ee }\end{array}$} & \multicolumn{2}{|c|}{$\begin{array}{c}\text { No } \\
\text { idea }\end{array}$} \\
\hline & & n & $\%$ & n & $\%$ & $\mathbf{n}$ & $\%$ \\
\hline 1 & $\begin{array}{l}\text { The use of humor makes } \\
\text { me relax and helps me } \\
\text { reduce stress in learning } \\
\text { English }\end{array}$ & 60 & 100 & 0 & 0 & 0 & 0 \\
\hline 2 & $\begin{array}{l}\text { Humor bridges the gap } \\
\text { between lecturers and } \\
\text { students. }\end{array}$ & 49 & 82 & 8 & $\begin{array}{l}1 \\
3\end{array}$ & 3 & 5 \\
\hline 3 & $\begin{array}{l}\text { The use of Humor makes } \\
\text { the English class more } \\
\text { interesting. }\end{array}$ & 57 & 95 & 2 & 3 & 1 & 2 \\
\hline 4 & $\begin{array}{l}\text { The use of Humor } \\
\text { encourages the students to } \\
\text { attend the class }\end{array}$ & 45 & 75 & $\begin{array}{l}1 \\
5\end{array}$ & $\begin{array}{l}2 \\
5\end{array}$ & 0 & 0 \\
\hline 5 & $\begin{array}{l}\text { The use of humor helps } \\
\text { me to understand and } \\
\text { remember the material } \\
\text { being taught easily }\end{array}$ & 58 & 97 & 2 & 3 & 0 & 0 \\
\hline
\end{tabular}

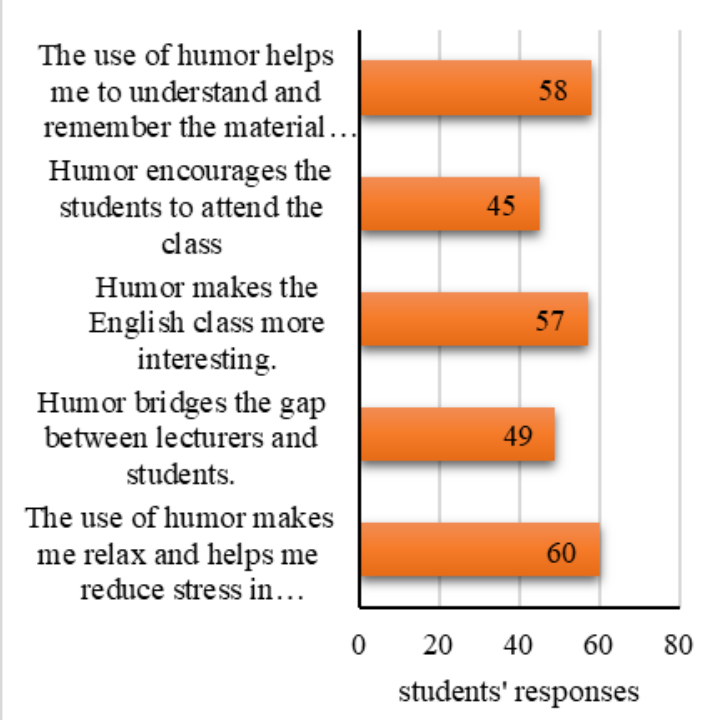

Fig. 2. The distribution of Students' Agreement

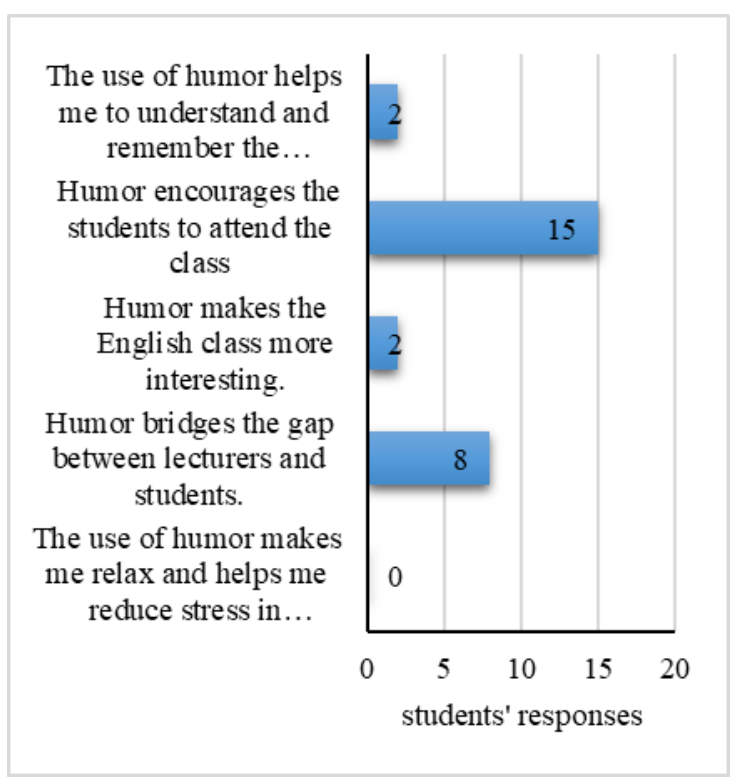

Fig. 3. The distribution of Students' Disagreement

\section{CONCLUSION}

The result of the inquiry showed that majority of the students perceived English Language as a difficult subject. The obstacle such as boredom and feeling stress could arise during the teaching and learning process. Therefore, teacher or lecturer can help the students to tackle down such hindrance by utilizing humor in classroom instruction.

Most of the respondents are strongly supported the idea that the use of humor in the classroom teaching setting creates a more comfortable learning atmosphere which make them feel relaxed and less stress during the lesson. Hence, humor makes the students develop the sense that a difficult subject like English language become an interesting subject. Furthermore, the use of humor also helps the lecture to have a better communication with the students by reducing teacher - student gap because the students feel that the lecture is approachable. Humor helps the students to have better retention on the material that they learned. Overall, the study revealed that students have positive attitudes toward the use of humor as the instructional tool in the classroom teaching setting. However, a further investigation is needed to find out why humor does not quite promote students' attendance.

\section{ACKNOWLEDGMENT}

This work was supported by Universitas Musamus Merauke. Therefore, the writers would like to convey the gratitude to the Rector of Musamus University and the Dean of Faculty of Teacher Training and Education Musamus University for their support and facilities during the research.

\section{REFERENCES}

[1] S. D. Krashen, Principles and Practice in Second Language Acquisition. Prentice-Hall International, 1987.

[2] R. A. Berk, "Humor as an instructional defibrillator.," J. Health Adm. Educ., 2007.

[4] L. Askildson, "Effects of Humor in the Language Classroom: Humor as a Pedagogical Tool in Theory and Practice," Work. Pap. SLAT, 2005.

[5] N. Webster, Merriam-Webster Online's Dictionary and Thesaurus. 1996.

[6] V. M. Robinson, Humor and the health professions. New Jersey: Charles B. Slack, 1977.

[7] Oxford University Press, "Oxford Advanced Learner's Dictionary (Seventh Edition),” Oxford University Press, 2020. .

[8] V. Raskin and V. Raskin, "Semantic Theory of Humor," in Semantic Mechanisms of Humor, 1985.

[9] M. P. Bennett, J. M. Zeller, L. Rosenberg, and J. McCann, "The effect of mirthful laughter on stress and natural killer cell activity," Altern. Ther. Health Med., 2003.

[10] R. McMaster, "A Dash of Humor Ups Performance and Creativity at "A Dark." http://brainbasedbiz.blogspot.com/2008/09/dash-of-humor-upsperformance-and.html.

R. . Griffin, "Give Your Body a Boost - with Laughter," WebMD, 2006. .

[12] J. Wilkins and A. J. Eisenbraun, "Humor theories and the physiological benefits of laughter," Holist. Nurs. Pract., 2009, doi: 10.1097/HNP.0b013e3181bf37ad.

[13] M. H. Abel, "Humor, stress, and coping strategies," Humor, 
2002, doi: 10.1515/humr.15.4.365.

[14] S. Ghayas and F. Malik, "Sense of Humor as Predictor of Creativity Level in University Undergraduates," J. Behav. Sci., 2013.

[15] J.Knox, "Letter from The President," Humor Connection, the Association For Applied And Therapeutic Humor., 2013.

[16] M. Kerr, "Putting Mimes to Good Use: Three Reasons Humor Can Help You Spread the Word at Work," inspiring workplace.
[17] R. M. Kaplan and G. C. Pascoe, "Humorous lectures and humorous examples: Some effects upon comprehension and retention.," J. Educ. Psychol., 1977, doi: 10.1037//00220663.69.1.61.

[18] M. K. Morrison, Using Humor to Maximize Learning: The Links between Positive Emotions and Education. Maryland: Rowman \& Littlefield Education, 2008. 